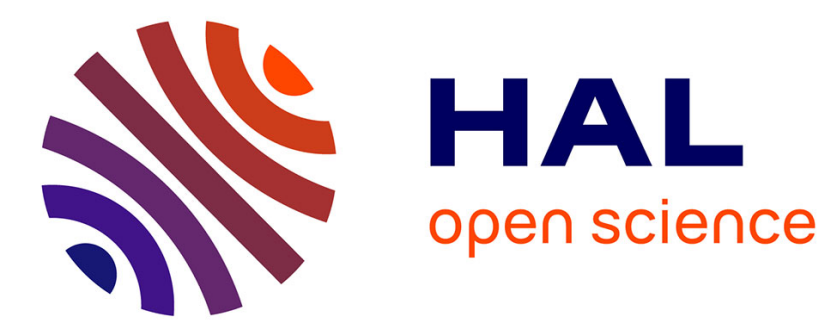

\title{
Bioavailability of caseinophosphopeptide-bound iron
}

Nabil Ait-Oukhatar, Jean Michel Peres, Said Bouhallab, Dominique Neuville, Francois Bureau, Gerard Bouvard, Pierre Arhan, Dominique Bougle

\section{To cite this version:}

Nabil Ait-Oukhatar, Jean Michel Peres, Said Bouhallab, Dominique Neuville, Francois Bureau, et al.. Bioavailability of caseinophosphopeptide-bound iron. Journal of Laboratory and Clinical Medicine, 2002, 140 (4), pp.290-294. 10.1067/mlc.2002.128146 . hal-01568870

\section{HAL Id: hal-01568870 \\ https://hal.science/hal-01568870}

Submitted on 25 Jul 2017

HAL is a multi-disciplinary open access archive for the deposit and dissemination of scientific research documents, whether they are published or not. The documents may come from teaching and research institutions in France or abroad, or from public or private research centers.
L'archive ouverte pluridisciplinaire HAL, est destinée au dépôt et à la diffusion de documents scientifiques de niveau recherche, publiés ou non, émanant des établissements d'enseignement et de recherche français ou étrangers, des laboratoires publics ou privés.

\section{다(1)(2)}

Distributed under a Creative Commons Attribution - ShareAlike| 4.0 International 


\title{
Bioavailability of caseinophosphopeptide-bound iron
}

\author{
NABIL AIT-OUKHATAR, JEAN MICHEL PERES, SAID BOUHALLAB, DOMINIQUE NEUVILLE, \\ FRANCOIS BUREAU, GERARD BOUVARD, PIERRE ARHAN, and DOMINIQUE BOUGLE
}

CAEN and RENNES, FRANCE

Iron deficiency, one of the main worldwide nutritional deficiencies, results from the low bioavailability of most dietary iron, including cow milk. Hydrolysis of the cow milk protein casein produces low molecular weight caseinophosphopeptides (CPPs). Binding of iron to CPPs keeps it soluble in the digestive tract and prevents the formation of high molecular weight ferric hydroxides, which are poorly absorbed. Previous experimental studies have shown that iron bound to the phosphopeptide containing the first 25 amino acids of $\beta$-casein, or $\beta-C N(1-25)$, is well absorbed and corrects efficiently iron deficiency. We sought to assess in vivo iron absorption and uptake by tissues involved in iron metabolism and storage (liver, spleen, bone marrow), using radiolabeled iron. $\beta-C N$ (1-25)-Fe displayed better absorption and tissue uptake by the vascularized rat loop model compared with a control substance, ferric ascorbate. The metabolism of $\beta-C N$ (1-25)-Fe labeled with iron 59, added to cow milk, was also studied in young women. Although the absorption of $\boldsymbol{\beta}-\mathrm{CN}$ (1-25)-Fe was not significantly higher than that of ferrous sulfate, it displayed significantly higher tissue uptake. This increase was transient and had disappeared by the 14th day of the study, suggesting that iron was used for metabolic purposes. (J Lab Clin Med 2002;140:290-4)

Abreviations: $\mathbf{C N}=$ casein; CPP: caseinophosphopeptide; $\beta-C N(1-25)-F e=$ first 25 amino acids of $\beta$-casein-bound iron; $\beta$-CN (1-25) = first 25 amino acids of $\beta$-casein

D igestion of milk proteins releases numerous bioactive peptides encoded in the native proteins. They display specific physiological functions in gastrointestinal, immunological, hormonal, and nutritional responses. ${ }^{1,2}$

Among them, CPPs issued from casein hydrolysis have the ability to bind and keep soluble cations; ${ }^{3,4}$ they improve calcium and zinc absorption. ${ }^{5}$ Indeed, intact

From the Laboratoire de Physiologie Digestive et Nutritionnelle, Laboratoire de Biochimie A, and Service des Radio-Isotopes, CHU de Caen; and the Laboratoire de Recherches de Technologie Laitière, INRA, Rennes, France.

Supported in part by Diépal nsa, Groupe Danone.

Submitted for publication January 2, 2002; revision submitted April 8, 2002; accepted May 15, 2002.

Reprint requests: Dominique Bouglé, Service de Pédiatrie A, CHU Clémenceau, CHU de Caen F-14033, Caen Cedex, France; e-mail: bougle-d@chu-caen.fr.

Copyright $\odot 2002$ by Mosby, Inc. All rights reserved.

$0022-2143 / 2002 \$ 35.00+0 \quad \mathbf{5 / 1 / 1 2 8 1 4 6}$

doi:10.1067/mlc.2002.128146 bovine milk proteins keep iron soluble in the digestive tract but inhibit its absorption unless they are hydrolyzed. ${ }^{6}$ The use of CPP instead of native proteins might improve iron absorption.

The $N$-terminal CPP issued from the trypsin hydrolysis of $\beta-\mathrm{CN}$ is one of the main CPPs produced in vivo during digestion ${ }^{7}$; previous experimental studies in rats have shown that $\beta-\mathrm{CN}$ (1-25)-bound iron remains soluble in the digestive tract, where it escapes further enzyme digestion. ${ }^{7,8}$ The absorption of $\beta-\mathrm{CN} 1-25-$ bound iron occurs partly through endocytosis and is more efficient than the absorption of gluconate iron'; repletion with $\beta \mathrm{CN}$ (1-25)-bound iron also results in significantly greater improvement of hemoglobin and iron concentrations in related tissues (liver, spleen) in iron-deficient rats than repletion with $\mathrm{FeSO}_{4} \cdot{ }^{10}$ Using iron 59-labeled iron, we assessed in vivo the metabolism of absorbed iron in rats and compared these results with the metabolism of absorbed iron in human beings.

We compared the vascularized duodenal rat loop model with iron absorption on the basis of the deter- 
mination of radioactivity incorporated into circulating red blood cells, as well as tissue uptake, in young women.

\section{METHODS}

Preparation of $\boldsymbol{\beta}-\mathrm{CN}$ (1-25)-bound iron. $\beta-\mathrm{CN}(1-25)$ (purity $>85 \%$ ) was purified from tryptic hydrolysate of $\beta$-CN as previously described. ${ }^{8}$

We bound iron by mixing $\beta$-CN (1-25) with a $\mathrm{FeCl}_{2}$ solution for 1 hour at $37^{\circ} \mathrm{C}$ and a $\mathrm{pH}$ of 6.5. The resulting solutions were then ultrafiltered and diafiltered on a $3-\mathrm{kD}$ membrane to remove free minerals. The amount of iron complexed to phosphopeptides and the presence of traces of calcium and sodium were determined with the use of atomicabsorption spectrometry (Model AA 1275; Varian; Les Ulis, France) on freeze-dried samples. The final product had an iron/phosphopeptides molar ratio of 4 and contained less than $1 \mathrm{mg}$ sodium and $0.1 \mathrm{mg}$ calcium $/ \mathrm{g}$.

Labeling of iron. $\gamma$-Emitting ${ }^{59} \mathrm{Fe}$ was purchased from Amersham (Amersham Pharmacia Biotech, Orsay; specific activity $3.7 \mathrm{MBq} / \mathrm{mL}$ ). Perfusion solutes were extrinsically labeled in the laboratory with $\mathrm{FeCl}_{3}$ and mixed with cold ferric ascorbate at a ratio of $0.001 \%$, whereas the complex of $\beta$-CN (1-25)-bound iron was intrinsically labeled during its preparation.

For the human study, milk was labeled either with extrinsically tagged $\mathrm{FeSO}_{4}$ with ${ }^{59} \mathrm{Fe}$ citrate or with the intrinsically labeled $\beta$-CN (1-25)-Fe.

Each $250-\mathrm{mL}$ meal contained the same amount of radioactivity $(74 \mathrm{kBq})$.

Experimental study. In an experimental study of perfused rat duodenal loop, four groups (each group $n=6$ ) of adult Sprague-Dawley rats were studied after being fasted overnight, as previously described. ${ }^{9}$ They were perfused with ferric ascorbate or $\beta$-CN (1-25)-Fe. We tagged iron with ${ }^{59} \mathrm{Fe}$ so that we might assess iron tissue uptake in addition to its absorption.

The composition of the perfusion solute was adapted from Ringer-Lavoisier solute; its $\mathrm{pH}$ was adjusted to that of the proximal duodenum (5.5) and contained $100 \mu \mathrm{mol} / \mathrm{L}$ iron in either form.

Duodenum of anaesthetized rats was perfused at a delivery rate of $0.16 \mathrm{~mL} / \mathrm{min}$; every element of the perfusion device had been washed with a solution of Triton X-100 (1 g/L) to prevent contamination. We kept the perfusion solute at $37^{\circ} \mathrm{C}$ with a thermostatic control and added a nonabsorbable marker (polyethylene glycol 4000) to assess actual net water flux. After 2 hours of perfusion, the animal was killed with an overdose of Doléthal; then the perfused loop was withdrawn and washed with saline solution.

Tissues were digested in nitric acid. The radioactivity of gut mucosa, blood, liver, and spleen was measured on a scintillation counter.

Human study. Our human study was approved by the local committee of ethics. Ten subjects gave their written informed consent to participate: All were 20- to 30-year-old female students of the university, and all stated that they were in good health, had no recent history of digestive or inflamma- tory disease, or infection; were taking no medication or mineral supplementation; were using a chemical method of contraception; and had negative results on pregnancy testing.

Before the administration of the first test meal, blood was drawn for measurement of red blood cell count, serum ferritin, C-reactive protein (a marker of recent inflammation or infection), and background radioactivity.

The test subjects drank radioisotopically labeled milk after an overnight fast; nothing but water was allowed for the next 4 hours. All subjects drank $250 \mathrm{~mL}$ of sterilized milk containing $3 \mathrm{mg}$ iron $(12 \mathrm{mg} / \mathrm{L})$, either as $\mathrm{FeSO}_{4}$ or $\beta-\mathrm{CN}$ (1-25)-Fe, labeled with ${ }^{59} \mathrm{Fe}$. The two meals were given at random. The first was given on day 1 ; on day 14, blood was drawn to measure the increase in red blood cell radioactivity. External counting of liver, spleen, and blood marrow (sacrum) areas was performed on days 7 and 14 with the use of a solid scintillation counter equipped with a thick crystal for external isotope tissue measurement (CGR Nucléaire Médecine GM2C; Paris, France); counting lasted 10 minutes. The heart area was used as control, and background radioactivity was subtracted..$^{11}$

The second meal was given after a washout period of 2 weeks (day 28), after residual red blood cell and body radioactivity had been determined. External counting was performed on days 35 and 42; erythrocyte radioactivity was measured on day 42 .

Percentage absorption of iron was calculated on the basis of blood volume estimated from weight and height ${ }^{12}$ and an assumed hemoglobin incorporation of absorbed iron of $80 \% .^{13}$ In addition, data were corrected for background radioactivity and for the radioisotope decay of the residual radioactivity of tissues and red blood cells.

Statistical methods. We used Student's $t$ test to analyze data from the experimental study. Human data were subjected to analysis of variance and and Fisher's exact test. $P$ values of less than .05 were considered statistically significant.

\section{RESULTS}

Experimental study. The absorption of ferric ascorbate and $\beta$-CN (1-25)-Fe by isolated perfused rat duodenal loop system is shown in Table I. $\beta-\mathrm{CN}(1-25)-\mathrm{Fe}$ displayed greater gut uptake and net absorption, greater spleen uptake, and increased blood radioactivity compared with ferric ascorbate.

Human study. Hematologic data and results of ironabsorption testing are given in Table II. Three subjects were iron-deficient (ferritin concentration $<12 \mathrm{~g} / \mathrm{L}$ ).

Mean iron absorption was similar in the two groups, yet paired comparisons showed a nonsignificant trend toward better absorption of $\beta-\mathrm{CN}$ (1-25)-Fe.

Results of external counting are given in Fig 1. A significant difference was displayed at day 7 between $\mathrm{FeSO}_{4}$ and iron-labeled CPP for liver $(P=0.05)$, spleen $(P=0.05)$, and sacrum $(P=0.03)$; the total radioactivity of these organs was different between groups $(P=0.01)$ at day 7 . No difference was observed at day 14 . 
Table I. Absorption and tissue uptake of radiolabeled iron, given as iron ascorbate or $\beta$-CN (1-25)-bound iron, by rat duodenal loop

\begin{tabular}{|c|c|c|c|c|c|c|c|}
\hline Test substance & Mucosal uptake* & Mucosal retention* & Net absorption ${ }^{*}$ & Liver uptake* & Spleen uptake* & Blood activity* & Sum of tissue activit \\
\hline Iron ascorbate & $14.1 \pm 1.0^{*}$ & $6.2 \pm 0.5$ & $7.9 \pm 1.0$ & $4.7 \pm 0.3$ & $0.02 \pm 0.00$ & $3.0 \pm 0.6$ & $13.3 \pm 0.8$ \\
\hline $\begin{array}{l}\beta \mathrm{CN}(1-25)- \\
\mathrm{Fe}\end{array}$ & $18.2 \pm 1.2$ & $7.0 \pm 0.2$ & $11.2 \pm 1.1$ & $4.8 \pm 0.3$ & $0.03 \pm 0.01$ & $3.6 \pm 0.1$ & $15.4 \pm 0.3$ \\
\hline$P$ value & $<.001$ & .006 & $<.001$ & .49 & .022 & $<.001$ & $<.001$ \\
\hline
\end{tabular}

*Percent of dose perfused; mean $\pm \mathrm{SD}, \mathrm{n}=6$ per group. Initial iron concentration-100 $\mu \mathrm{mol}$.

tSum of mucosa, liver, spleen, and blood activity.

\section{DISCUSSION}

Iron deficiency remains a worldwide health problem, mainly involving growing infants and women of childbearing age. ${ }^{14}$ In addition, the side effects of iron supplementation limit adherence to its prescription, ${ }^{15}$ necessitating a search for highly bioavailable sources of iron, free of digestive interactions.

CPPs are produced during digestion of $\mathrm{CN}$; they bind divalent cations and keep them soluble at luminal $\mathrm{pH}^{7,16,17}$ The strength of iron binding to CPP is about 100 times greater than that of calcium and others cat-

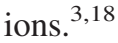

When assessed in rats on the basis of metabolic balance and direct measurement of tissue storage, the bioavailability of iron bound to $\beta-\mathrm{CN}$ (1-25) is higher than that of reference iron salts gluconate or ferrous sulfate. .,10 $^{9}$

In this study, the absorption rate and tissue uptake of $\mathrm{Fe}^{59}$ were similar to those noted in recent reports. ${ }^{19}$ Our findings showed that absorption, blood content, and spleen uptake of $\beta$-CN (1-25)-bound iron by duodenal rat loop during the experiment were better than that of inorganic iron. The better absorption and tissue uptake of $\beta$-CN (1-25) bound iron supports the results of tissue analysis after a 4-week repletion period..$^{9,10}$

Results varied between the rat and human groups. Differences in experimental methods could explain the isotopic data in the human group, in which iron-absorption rates were close to those obtained from studies that employed cow milk as source of iron. ${ }^{6,20-23}$ As expected, ${ }^{24}$ these results differed quantitatively from those of the rat group but displayed the same trends; some differences between the two experiments could explain the lower significance in the human trial. First, iron was given in milk and not in a pure solution as in the rat group. This decreases iron absorption and blunts differences between dietary sources of iron. ${ }^{14}$ Second, physiologic changes, such as the onset of menses, could have occurred during the time elapsed between the two tests in the human group. Use of ${ }^{55} \mathrm{Fe}$ and ${ }^{59} \mathrm{Fe}$ on consecutive days could have alleviated these potential variations, but the use of $\beta$-emitting ${ }^{55} \mathrm{Fe}$ precludes external counting.

Although stable isotopes are valid tools in the assessment of iron absorption from food, ${ }^{25,26}$ they do not supply information on tissue kinetics, as radioisotopes

Table II. Clinical details and iron absorption rate by human subjects given $3 \mathrm{mg}$ of iron tagged with ${ }^{59} \mathrm{Fe}$, either bound to $\beta-\mathrm{CN}(1-25)$ or as $\mathrm{FeSO}_{4}$ in $250 \mathrm{~mL}$ milk

\begin{tabular}{|c|c|c|c|c|c|}
\hline \multirow[b]{2}{*}{ Subject } & \multirow[b]{2}{*}{ Ferritin $(g / L)$} & \multirow[b]{2}{*}{ Hemoglobin $(\mathrm{g} / \mathrm{dL})$} & \multicolumn{2}{|c|}{ Iron absorption (\%) } & \multirow{2}{*}{$\begin{array}{c}\text { Ratio of } \\
\beta-\mathrm{CN}(1-25)-\mathrm{Fe} \\
\text { to } \mathrm{FeSO}_{4}\end{array}$} \\
\hline & & & $\beta-\mathrm{CN}(1-25)-\mathrm{Fe}$ & $\mathrm{FeSO}_{4}$ & \\
\hline 1 & 36 & 14.4 & 24.3 & 19.6 & 1.24 \\
\hline 2 & 24 & 13.2 & 4.4 & 6.9 & 0.65 \\
\hline 3 & 45 & 12.4 & 19.8 & 19.3 & 1.03 \\
\hline 4 & 5 & 14.8 & 14.6 & 18.4 & 0.80 \\
\hline 5 & 48 & 13.3 & 4.2 & 2.1 & 2.05 \\
\hline 6 & 31 & 14.1 & 10.2 & 9.5 & 1.08 \\
\hline 7 & 11 & 11.6 & 9.7 & 26.5 & 0.37 \\
\hline 8 & 40 & 12 & 7.7 & 1.8 & 4.37 \\
\hline 9 & 4 & 11.4 & 22.6 & 16.6 & 1.36 \\
\hline 10 & 33 & 14.3 & 5.3 & 2.8 & 1.92 \\
\hline Mean $\pm S D$ & $27.7 \pm 16.1$ & $13.1 \pm 0.4$ & $9.8 \pm 6.1$ & $9.9 \pm 7.1$ & $1.49 \pm 0.36^{*}$ \\
\hline
\end{tabular}

*Wilcoxon's test not significant. 


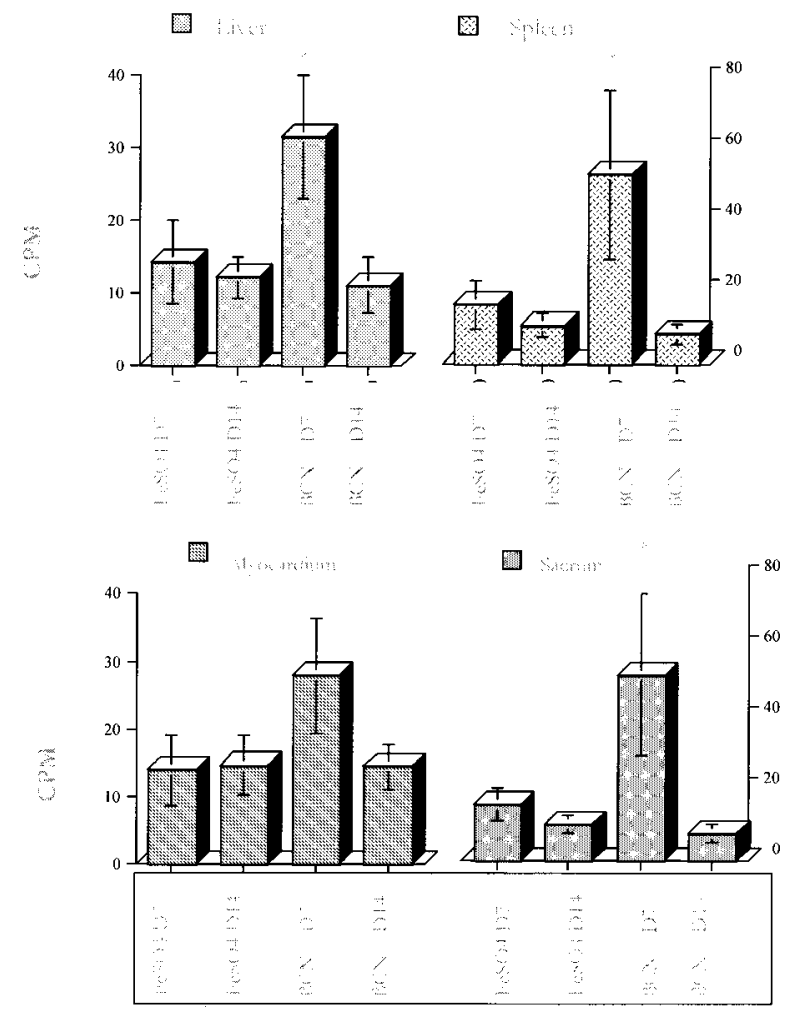

Fig 1. External counting of liver, spleen, sacrum, and myocardial areas of human subjects given $3 \mathrm{mg}$ iron tagged with ${ }^{59} \mathrm{Fe}$, either bound to $\beta$-CN (1-25) or as $\mathrm{FeSO}_{4}$, in $250 \mathrm{~mL}$ milk.

*Analysis of variance and Fisher's exact test, $\mathrm{FeSO}_{4}$ vs $\beta$-CN (1-25) at day $7(P<.05)$.

do. Our results suggest that tissue uptake of $\beta-\mathrm{CN}$ (1-25)-bound iron was significantly enhanced; this assumption is supported by the findings of our experimental study of the rat group, in which tissues were assessed immediately after absorption. The transient increase of iron concerned every organ involved in iron metabolism (bone marrow, liver, and spleen). Yet the function of iron uptake remains unclear; it may merely reflect the difference of radioactivity in the blood because blood was not removed before counting; however, counting of the blood-filled myocardial tissue did not display significant differences. Stored iron was quickly used: No difference was found 1 week later.

However, these data suggest that measuring only iron radioactivity incorporated into circulating erythrocytes could miss some differences in iron bioavailability, as noted by Fomon in newborn infants ${ }^{27}$; it is not known whether the observed differences concern iron absorption or kinetics.

Our findings show that in experimental models, iron bound to $\beta-\mathrm{CN}$ (1-25) displayed better absorption and better tissue uptake than inorganic salts; similarly, the findings of external counting of organs was temporarily enhanced in human subjects after intake of $\beta \mathrm{CN}$ (125)-bound iron.

These beneficial results may partly explain the high iron bioavailability of breast milk, which is rich in $\beta$-CN.

Further human studies are needed to precisely assess the bioavailability of $\beta$-CN (1-25)-bound iron, particularly the lack of interaction with other minerals previously shown in experimental studies.

\section{REFERENCES}

1. Bos C, Gaudichon C, Tomé D. Nutritional and physiological criteria in the assessment of milk protein quality for humans. J Am Coll Nutr 2000;19:191S-205.

2. Clare DA, Swaisgood HE. Bioactive milk peptides: a prospectus. J Dairy Sci 2000;83:1187-95.

3. Brulé G, Fauquant J. Interaction des protéines du lait et des oligo-éléments. Lait 1982;62:323-31.

4. Bouhallab S, Léonil J, Maubois JL. Complexation du fer par le phosphopeptide (1-25) de la caséine $\beta$ : action de l'alcalase et de la phosphatase acide. Lait 1991;71:435-43.

5. Hansen M, Sandström B, Lönnerdal B. The effect of casein phosphopeptides on zinc and calcium absorption from high phytates infant diets assessed in rat pups and Caco-2 cells. Pediatr Res 1996;40:547-52.

6. Hurrell RF, Lynch SR, Trinidad PT, Dassenko SA, Cook JD Iron absorption in humans as influenced by bovine milk proteins. Am J Clin Nutr 1989;49:546-52.

7. Naito H, Suzuki H. Further evidence for the formation in vivo of phosphopeptide in the intestinal lumen from dietary $\beta$-casein. Agr Biol Chem 1974;38:1543-5.

8. Bouhallab S, Aitt-Oukhatar N, Mollé D, Henry G, Maubois JL, Arhan P, et al. Sensitivity of $\beta$-casein phosphopeptide-iron complex to digestive enzymes in ligated segment of rat duodenum. J Nutr Biochem 1999;10:723-7.

9. Pérès JM, Bouhallab S, Bureau F, Neuville D, Maubois JL, Arhan P, et al. Mechanisms of absorption of caseinophosphopeptide bound iron. J Nutr Biochem 1999;10:215-22.

10. Aït-Oukhatar N, Bouhallab S, Arhan P, Maubois JL, Drosdowsky M, Bouglé D. Iron tissue storage and hemoglobin levels of deficient rats repleted with iron bound to the casein phosphopeptide 1-25 of $\beta$ casein. J Agric Food Chem 1999;47:2786-90.

11. Najean Y. Etude de l'absorption du fer. In: Najean Y, Ardeillon $\mathrm{N}$, Dresch $\mathrm{C}$, eds. Utilisation des techniques isotopiques en hématologie. Paris: Baillère Eds, 1969:83-91.

12. Brown E, Hoper J Jr, Hodges JL Jr, Bradley B, Wennesland R, Yamauchi H. Red cell, plasma, and blood volume in healthy women measured by radiochromium cell-labelling and hematocrit. J Clin Invest 1962;41:2182-90.

13. Hosain F, Marsaglia G, Finch CA. Blood ferrokinetics in normal man. J Clin Invest 1967;46:1-9.

14. Hurrell RF. Bioavailability of iron. Eur J Clin Nutr 1997; 51(suppl 1):S4-8.

15. Frykman E, Bystrom M, Hansen T. Side effects of iron supplementation in blood donors: superior tolerance of heme iron. J Lab Clin Med 1994;123:561-4.

16. Berrocal R, Chanton S, Juillerat MA, Pavillard B, Scherz JC, Jost R. Tryptic phosphopeptides from whole casein. II. Physicochemical properties related to the solubilization of calcium. J Dairy Res 1989;56:335-41.

17. Sato R, Shindo M, Gunshin H, Noguchi T, Naito H. Character- 
ization of phosphopeptide derived from bovine $\beta$-casein: an inhibitor to intra-intestinal precipitation of calcium phosphate. Biochim Biophys Acta 1991;1077:413-5.

18. Emery T. Iron oxidation by casein. Biochem Biophys Res Commun 1991;182:1047-52.

19. Benito P, House W, Miller D. Influence of iron supplementation frequency on absorption efficiency and mucosal ferritin in anaemic rats. Br J Nutr 1997;78:469-77.

20. Deehr MS, Dallal GE, Smith KT, Taulbee JD, Dawson-Hugues B. Effects of different calcium sources on iron absorption in postmenopausal women. Am J Clin Nutr 1990;51:95-9.

21. Galan P, Cherouvrier F, Preziosi P, Hercberg S. Effects of the increasing consumption of dairy products upon iron absorption. Eur J Clin Nutr 1991;45:553-9.

22. Gleerup A, Rossander-Hulthén L, Gramatkovski E, Hallberg L. Iron absorption from the whole diet: comparison of the effect of two different distributions of daily calcium intake. Am J Clin Nutr 1995;61:97-104.

23. Hurrell RF, Davidsson L, Reddy M, Kastenmayer P, Cook JD. A comparison of iron absorption in adults and infants consuming identical infant formulas. Br J Nutr 1998;79:31-6.

24. Reddy MB, Cook JD. Assessment of dietary determinants of nonheme-iron absorption in humans and rats. Am J Clin Nutr 1991;54:723-8.

25. Barrett JFR, Whittaker PG, Fenwick JD, Williams JG, Lind T. Comparison of stable isotopes and radioisotopes in the measurement of iron absorption in healthy women. Clin Sci 1994;87:91-5.

26. Aggett PJ. Iron, copper, and zinc absorption and turnover: the use of stable isotopes. Eur J Pediatr 1997;156(Suppl 1):S29-34.

27. Fomon SJ, Ziegler EE, Serfass EE, Nelson SE, Rogers RR, Frantz JA. Less than $80 \%$ of absorbed iron is promptly incorporated into erythrocytes of infants. J Nutr 2000;130:45-52. 